\title{
Introduction
}

\section{The purānas}

The purānas are an important genre of Hindu literature. ${ }^{1}$ Together they constitute an authoritative archive-cosmogony and cosmology, theology and mythology as well as orthodoxy and orthopraxis-for Hindu traditions. Many important narratives relating to the deities Viṣnu-Kṛṣna, Siva and the great goddess Devī are found in their most authoritative form in purānic texts. These narratives-along with the two epics, the Mahābhärata and the Rámāyana-form the beating heart of Hindu identity and imagination. To be Hindu is to have internalised this purānic thought-world.

Traditionally, there are said to be eighteen great purānas and an equal number of lesser ones, although the membership of each category varies from one source to another. In addition, there are probably thousands of local purānas, ancient and modern, in Sanskrit and vernacular languages, which preserve accounts of specific sacred sites, communities and religious practices.

The great purānas are composed in Sanskrit-the elite language of scholarly and priestly discourse in premodern India. Ironically, the most authoritative forms of these narratives are preserved in a language inaccessible to the majority of the faith community, both then and now. Purānic narratives, though preserved in Sanskrit, are widely reproduced in popular vernaculars, not to mention the visual arts, drama, film and television and now, like everything else, online and through mobile apps.

1 The best general introduction to the purānas is Bailey (2018). See also Matchett (2005) and Rao (2007). For more detail on individual purāṇas, see Rocher (1986). 
Most of the great purānas are thought to have reached their current state between 400 and $1500 \mathrm{CE}$ or later. The most recent strata of the Bhavisya Purāna, for example, famously prophesises the existence of Queen Victoria's Calcutta, and must therefore have been either uncommonly prescient or completed during or after that monarch's reign (Hiltebeitel 1999: 277).

Most purānas are substantial bodies of literature, ranging from 10,000 to 20,000 verses. The outlier is the giant, sprawling Skanda Purāna at more than 80,000 verses. The Viṣnu Purāna, which runs to about 5,600 verses or 15,000 lines, is among the more modest members of the genre. For comparison, Homer's Odyssey and Iliad are both about the same length as this text, as is a typical volume of Harry Potter.

By theirown definition, purānasare supposed to exhibit five characteristicsthe pañca-laksana - and address five main themes: ${ }^{2}$ the initial creation of the universe out of nothing (sarga), its subsequent re-creation after each cyclical destruction (pratisarga), the genealogies of the gods and patriarchs (vamsa), the reigns of fourteen mythical progenitors known as Manus (manvantara) and the history of two dynasties, the Solar and the Lunar (vamśa-anucarita).

There is great variation in the degree to which individual purānas adhere to this scheme. At one end of the spectrum is the Agni Puranna - an extensive encyclopedia of cultural, scientific and literary snippets-which dispenses with the pañca-lakșana in a few pages. The Viṣnu Purāna is at the other end of the spectrum and, of all the major purānas, is most closely structured in accordance with this scheme.

These five topics constitute the bulk of the Viṣnu Purāna's content and are covered more or less systematically in its six books, but with devotional and other practical guidance for daily life included here and there. The description of the Lunar Dynasty balloons out to fill Books Four and Five, as these contain the account of Kṛnna's forebears and the deeds of the deity himself. The final book, dealing with various forms of dissolution, rightly belongs to the second lakșana, which includes both the creation and the destruction of the universe, but the end of the book is perhaps a more appropriate place to describe the end of the world. This arrangement also reinforces the overall chronological structure of the Viṣnu Purāna.

2 On the pañca-lakșana, see Schreiner (2002). 


\section{The Viṣnu Purāṇa}

In so far as the Viṣnu Purāna has a single thrust or goal, it is to instil and heighten a sense of devotion to the deity in all his various forms. As the text says of itself: 'Lord Viṣnu is mentioned at every stage, including the creation, re-creation, genealogies, Manvantaras and the rest without exception, best of brahmins' (3.6.26). It seeks to inspire devotion to the deity by continually emphasising his all-embracing and universal nature and by demonstrating that, by singing the deity's praises with devotion, gods, mortals and even demons get what they want-either earthly success or divine liberation.

This text is thought to have arisen at a time in Indian history when there was much competition in the spiritual marketplace among various traditions. Then, as now, traditions need to attract and retain devotees to survive. They can only maintain and perpetuate themselves with the energy and resources provided by the faithful. The Viṣnu Purāna seeks to achieve this goal by confirming and constantly reconfirming the centrality of the deity in all creation. It describes the spiritual journey of exemplary devotees such as the young prince Dhruva and the demon boy Prahlāda, who escape the torments of existence through extreme devotion and piety. These model devotees eventually achieve a state of mystical union with Viṣnu and thereby win liberation from samsāra - the otherwise endless cycle of birth, death and rebirth. This search for liberation or moksa is the ultimate goal, not only of Hindu traditions of which the Viṣnu Purāna is a part, but also of the other Indic religions, Buddhism and Jainism. Liberation leads to a state of nonexistence or nirvāna.

The Viṣnu Purāna has a socially conservative subtext. At every step, it asserts the superiority of the priestly community of brahmins at the expense of the other orders that constitute its idealised society: the warrior, merchant and serving classes-the kșatriyas, vaisyas and siudras. Brahmins were placed by the Creator at the apex of the social hierarchy and are to be honoured, paid, fed and served by everyone else. The most heinous crime is brahminicide, and without brahmins to conduct the sacrifice that nourishes the gods, the world would perish.

The social conservatism of the Viṣnu Purāna is also evident in terms of gender. This is a text composed by men and for men in a patriarchal society. Women are primarily wives and mothers whose role is to bear sons to perpetuate the male line. At one point, we read that children really belong 
to the father as he is the source of semen, while 'a mother is but a pouch of skin' (4.19.1). Fidelity to her husband is a woman's primary virtue. Nonhuman female characters, such as the Earth and cows, need to be uplifted, rescued and protected by males. The only other role for women is as the 'fair-hipped', 'almond-eyed' seductress who tempts pious men from the path of virtue.

One bright spot for female characters is found in the song of praise offered to the goddess Lakṣmī, Viṣnu's consort (1.8.16-34). Here, the qualities of the divine couple are compared in relatively equal and complementary terms: Viṣnu is 'meaning' and his partner is 'the word', and so on. Nevertheless, the Viṣnu Purāna remains the product of the patriarchal system in which it is clearly invested.

\section{Problems with dating}

The dating of Sanskrit texts is always problematic, as they exist in multiple versions and have evolved over many centuries. Traditionally inscribed on palm leaves or birch bark, manuscripts perish in the hot and humid Indian climate. It has been said that the most enthusiastic consumer of Sanskrit manuscripts is 'His Majesty the Bookworm'. Even after paper was introduced in the thirteenth century, manuscripts had to be recopied every few generations. Each time a scribe sat down to write out an old worm-eaten manuscript, he or his sponsor might seek to 'improve' the text by adding a story here or inserting a discourse there. Purānas, like a premodern Sanskritic Wikipedia, thus evolved under many hands over many generations. ${ }^{3}$ The result is that texts in their final form can seldom be assigned accurately to a single time, place or author.

Ironically, for the past two centuries or more, Western scholarship has tended to prioritise the oldest and therefore most 'original' version of a text. Scholars have regarded 'improvements' carried out by premodern scribes as corruptions or contaminations. Some Indological research is also criticised for being ahistorical - that is, for neglecting to address a text in its historical, political, social or economic context. But how is one to assign a text to a specific context when it has been in circulation across the length and breadth of the Indic world for a millennium or more? This problem remains unresolved.

3 I owe this simile to Wendy Doniger. 
My particular approach has been to use current practice as an analogy. The modes in which texts are 'consumed' today may cast light on how they were used in the past. After all, the ideological context of these texts-the 'purānic thought-world' - remains intact alongside and within modernity, and the discourses conjured by texts like the Viṣnu Purāna still resonate with audiences in the faith community today.

While it is impossible to assign an exact date to the Viṣnu Purāna, we can position it relative to some of the other Sanskrit classics. We know, for example, that our text is later than the epics the Mahäbhärata and the Rammayana-which are thought to have reached their current form before the fourth or fifth centuries CE (van Buitenen 1973: xxv; Goldman 1984: 14) - as it makes many references to them. The Viṣnu Purāna is probably older than the Bhägavata Purāna, which dates from the eighth to tenth centuries at the latest (Holdrege 2013: 92; Hardy 1983), as our text is simpler in structure, less elaborate in diction and exhibits a lessdeveloped sense of bhakti-the intense personal sentiment of devotion to the divine. It seems reasonable to guess-but little more than guess-that the Viṣnu Purāna reached its current extent between the fourth and fifth centuries CE (Couture 2014; Schreiner 2013: 592).

The various dates mentioned above tend to align these important Sanskrit texts with the period of the Gupta Empire, one of India's 'Golden Ages', which flourished between 319 and $543 \mathrm{CE}$. This period witnessed a number of important changes in Indian society. Religious practices that had been the exclusive province of the brahmin elite now devolved towards individuals who were able to perform domestic and temple-based rituals themselves. There was rising competition for royal patronage and spiritual leadership among different traditions. These included Hindu schools centred on the deities Viṣnu, Śiva and the great goddess Devĩ and 'heretical' schools including Jain, Buddhist and Tantric practitioners. All of these challenged the old Vedic order and are thought to have weakened the financial, social and ideological preeminence that the brahmins had enjoyed. Some scholars see the appearance of purānic literature as a brahminical response to these changing conditions. Brahmins wrote purānas to cement their place at the centre of the social order, and they were a means by which the authors sought to reclaim and maintain their social capital, which was increasingly under threat (Sathaye 2015: 111-112). 


\section{Authorship}

Modern readers generally like to know who wrote the text they are reading, but the master works of the Sanskritic scriptural archive are all anonymous or, more accurately, pseudonymous. Not only are successive generations of individual originators, authors, editors and scribes unnamed, they also usually attempt to conceal all evidence of the human hand. The closest we come to a human author may be a legendary sage such as Vyāsa, but even then, he is often just an intermediary between gods and mortals. Most of the classics are ascribed to one or other deity. Texts like this one are said to have been passed down orally through glittering lineages of gods and semidivine seers until they descended to the human realm.

A more prosaic account of authorship must acknowledge the fact that the Viṣnu Purāna was composed in Sanskrit, so the creators, as we have seen, are likely to have been male members of the brahmin community, who were the literary elite. Not surprisingly, they are clearly exponents of the Vaisnnava tradition and have access to an encyclopedic archive of Sanskritic mythology and dogma.

While academics are concerned with the age and authorship of this and other Sanskrit texts, and the historical context in which they arose, these questions are largely irrelevant for traditional audiences and members of the faith community, for whom scriptures like these are of divine origin and are more or less eternally present and ageless.

\section{The audience}

We know little more about the audiences of these texts than we know about their authors. There are hints from the visual arts and, in both sculpture and painting, we sometimes see teachers, text in hand, apparently delivering a lecture or teaching a class of students seated before them. We also occasionally come across figures reading or possibly reciting texts on their own.

I have argued elsewhere that modern practice might be a useful guide to premodern habits (Taylor 2016). While researching the contemporary performance of the Bhaggavata Purāna-a close relative of the Viṣnn Purāna-I identified three broad patterns of textual consumption. First, devout individuals literate in Sanskrit may read the text to themselves, 
either silently or in a low murmur, at the rate of a chapter or more a day. This is a means by which the reader may acquire religious merit and social capital. Second, a pious individual may engage a student or scholar to read the text on their behalf, in which case the sponsor earns the merit. Alternatively, a sponsor may dedicate the merit to someone else, such as a sick relative, an unmarried child or an aspiring student or professional.

The third way in which texts are experienced-and the one that reaches the largest audience-is through public oral performance. Again, a pious sponsor will engage a scholar to recite the text in part or in full before an audience. As Sanskrit has always been the language of an educated elite, these recitations are accompanied by an explanation in a local language that everyone can understand. The upshot of this is that the majority of people experience these texts aurally, through oral performance, rather than as text read privately, as in modern reading practice. All three modes of textual reproduction are believed to confer great merit on all concerned. While we do not have any direct evidence of how the Viṣnu Purạna was consumed in premodern times, these three patterns provide a useful proxy in the absence of better evidence.

\section{Relationship to other texts}

From the point of view of literary analysis, a typical purāna can be said to exhibit

a juxtaposition of mythic and didactic texts, a heavy dependence on earlier purānas as a source of content, the absolute predictability of the plots of its myths and its saturation with signifiers of a bhakti ideological referent. (Bailey 1995: 5)

This is certainly true of the Viṣnu Purāna. The bulk of the text consists of pañca-laksana material (the five generic themes mentioned above), which is primarily mythic. This is interspersed with didactic sections, particularly in the second half of Book Three, 'Society', which focuses on rituals and practices for daily life. Other important elements are the devotional passages, consisting mainly of songs in praise of the deity, and the genealogical sections, which will be discussed below.

In terms of the Viṣnu Purāna's reliance on earlier sources, it is obvious the text's creators were well acquainted with many narratives that go back to the Vedas, which themselves date at the very latest from the middle of 
the second millennium BCE. Episodes that are merely hinted at in those early sources are expanded and embellished here. The presence of Indra as king of gods and provider of rain and frequent references to the neverending struggle between the gods and demigods are among the more common elements of Vedic mythology carried over to the Viṣnu Puraña. The important Vedic myth about Viṣnu pacing out the world in three strides is also alluded to in our text.

The creators of the Viṣnu Purāna were well acquainted with the Mahäbhärata. In a passage in praise of the epic's reputed author, the sage Vyāsa, we find the following: 'Understand that Vyāsa, Kṛ̣nạa-Dvaipāyana, is Lord Nārāyana himself, Maitreya. Who else on earth could compose the Mabābharata?' (3.4.5). ${ }^{4}$ The genealogy of the five Pândava brothers, the heroes of the epic, is given in Book Four (4.14.9-10), and the Vișnu Purāna also quotes verses directly from the Mahābhārata with reference to the king Bharata (4.19.1-2). Elsewhere the plots of the Mabäbhärata and the Viṣnu Purāna intertwine when Kṛ̣ṇa visits Hastināpura after Duryodhana attempted to incinerate the Pānḍavas in the house of lacquer (4.13.26).

The story of Krṣna as an avatāra of Viṣnu is, of course, central to the latter part of the Viṣnu Purāna, and his childhood, youth and adult life occupy more than one-quarter of its entire extent. Kṛnna is also one of the central characters in the Mabābbārata, especially in his role as Arjuna's driver and confidant during the great eighteen-day war. The unique relationship between Kṛnna and Arjuna, which lies at the heart of the Mabābhärata in general and the Bhagavad Gita in particular, is foretold in Book Five of the Viṣnu Purāna. Indra advises the young Kṛ̣na that he, Indra, will manifest an aspect of himself on earth in the form of the warrior Arjuna, whom he will entrust to Kṛ̣nạ’s protection (5.12.15-18).

While Kṛ̣na is central to both the Mabābhärata and the Viṣnu Purāna, there is little overlap between their two accounts. The Vișnu Purāna focuses on Krṣna the boy, the amorous youth and his deeds as king of Dvārakā, but barely mentions the role he played in the Mahābhārata war, let alone his most famous discourse, the Bhagavad Gità. Conversely, the Mahābhārata describes in great detail Kṛ̣na’s dealings with the Pāṇava family and his role in the war and does not record any of the events of his childhood or youth.

4 All references to the Mahābhärata are from the Critical Edition (Sukthankar 1933-66). 
The Harivamśa (HV) describes itself as an appendix (kbila) to the Mahābhārata (Brodbeck 2019; Vaidya 1969). It is almost certainly earlier than the Visnu Purāna in its current form and may have been one of its sources. The Harivamía includes many episodes of Kṛ̣na’s pastimes (lìlā) and his battles with various demons. These accounts are also found in the Vișnu Puranna. Comparing the narratives in both sources, the versions in the Harivams'a are usually much longer, more detailed and closer in style to the martial cast of the Mabābbärata. The descriptions of some of Kṛ̣na's encounters with various demons in the Viṣnu Purāna, for example, are little more than caricatures when compared with earlier versions in the Harivamsá . The Viṣnu Purāna seems to skip with almost indecent haste from one episode to the next. Many of the events of Kṛnna's early life, which are fully fleshed out in rip-roaring detail in the Harivamsa (see, for example, the wrestling match and death of Kamsa, HV 72-76), are stripped to their bare narrative bones in the Viṣnu Purāna. I wonder whether the authors of the Viṣnu Purāna expected their audience to be so familiar with the specific episodes that there was no need to retell them in detail. On the other hand, they fill this narrative skeleton with songs of praise to elevate the sentiment of bhakti-an element conspicuously absent from the Harivamsa.

We cannot say with certainty whether the creators of the Viṣnu Puraña drew directly from the Harivams a or from some intermediate or common source. Nor can we be certain of the relationship between the Viṣnu Purāna and the Bhagavata Puranna. This later text attributes nearly double the number of miraculous feats to Kṛṣna and is saturated with the emotion of bhakti. Hardly a verse slips past without a sententious observation. These three sources occupy a continuum. The Harivamsa at one end is long on narrative and short on sentiment. In the middle is the Viṣnu Purāna, which is moderately concerned with both aspects. At the other extreme is the Bhägatava Puranna, which is less focused on narrative, but is strongly committed to devotion (Preciado-Solis 1984: 42).

The Viṣnu Purāna may have been a direct source or inspiration for the Bhägavata Purāna, but its relationship with another purāna, the Brabma, is also worth noting. For example, the narrative of the sage Kandu, who was distracted from his ascetic practice by the apsaras Pramlocã in the Vișnu Puranna (1.15.13-52), is found word for word with only trivial differences in the Brabma Puraña (69.69-106). Nearly one-quarter of the Viṣnu Purāna, covering the whole of the Kṛ̣na story, from his advent to his withdrawal from the world (5.1.22-5.38.93), is also found word for 
word in the Brabma Puranna (72.8-103.95). The only substantial change appears to be in the framing of the narrative. In the Viṣnu Purāna, Parāśara is narrating the story to Maitreya, but in the Brabma Purāna, Vyāsa is instructing a community of sages. It is generally assumed that the Viṣnu Purana is the earlier of the two, so the creators of the Brabma Purana appear to have copied the Viṣnu Purāna or some similar source. This in itself reveals something interesting about purānic intertextuality and the process of textual creation in Sanskritic literary culture.

\section{The nature of Viṣnu}

Viṣnu is often depicted as a bluish four-armed deity holding the discus known as Sudarśana (the 'Splendid One'), a mace, a lotus and a conch whose sound robs enemies of their strength. His consort Lakșmī (also known as Śrī), the goddess of prosperity, is sometimes standing by his side. Viṣnu is also seen reclining on the cosmic ocean, sheltered by the fanned hoods of the many-headed serpent Śeșa. The deity is usually wearing yellow robes, garlands and jewels. On his chest is a whorl of hair known as Śrīvatsa-a feature occasionally mentioned in the Viṣnu Purāna. When travelling, he rides on Garuda, king of birds and arch enemy of all serpents.

Viṣnu has been a member of the Hindu pantheon for a very long time, but he arose from humble beginnings. The $\mathrm{Rg} V \mathrm{Veda}$ (RV; see below) dates from, at the very latest, the second millennium before the current era. It contains just over 1,000 songs of praise to several dozen elemental deities, but only one song ( $R V$ 1.154) is dedicated exclusively to Viṣnu-specifically, his pacing out of the universe. Five others (RV 1.155, 1.156, 6.69, 7.99, 7.100) mention him in company with Indra, the king of gods. Viṣnu was certainly not one of the more prominent or significant deities at this early stage.

The Upanișads are a set of philosophical texts somewhat more recent than the Vedas. Here we see the emergence of the concept of brabman-an impersonal all-encompassing reality, of which all deities and the rest of creation are a part and which permeates everything. There is no suitable English equivalent for the term brabman, which I have reluctantly translated as 'the Absolute'. In the Upanișads, we start to see the idea that Viṣnu himself is indeed brahman, the supreme reality-a concept that thoroughly pervades the Viṣnu Purāna. To be fair, this same status is attributed to other deities as well. Within the Śaiva tradition, the deity Siva 
is said to be the highest Absolute, and in the Śākta tradition, it is the great goddess Devī. In later traditions, Kṛ̣na alone or with his consort Rādhā are equated with the Absolute at the heart of all reality.

Another important early thread of Hindu thought is the concept of the trimürti or 'three bodies'. These include the original Vedic creator deity, Brahmā (not to be confused with brabman), Viṣnu as the preserver and maintainer of the universe and Siva, also known as Rudra (the 'Terrible One'), who destroys the world at the end of each era. We frequently encounter this Hindu trinity in our text, but always with the understanding that Viṣnu is also the Absolute and highest overarching reality. Thus, Brahmā emerges from a lotus at Viṣnu's navel and creates the world at his behest. Viṣnu the Absolute awkwardly appears as Viṣnu the preserver, and even Śiva-Rudra the destroyer is a manifestation of this deity.

Cyclical existence-also known as rebirth, samsära, transmigration or reincarnation - lies at the heart of Hindu, Buddhist and Jain beliefs. With certain variations, these traditions share the idea that all beings possess an indestructible element-a soul, an ätman or a consciousness-which passes after death into another body. As a result of one's actions (karma) in this life, a being acquires merit or demerit and is consequently reborn in a more or less desirable womb. The hierarchy of lifeforms varies from tradition to tradition, but there is basic agreement that there are hell realms below us, then animals, we humans in the middle and gods above us. Lower lifeforms may move up the ladder if they are lucky, but even gods burn up their merit and eventually fall back to lower realms.

The cycle of birth, death and rebirth continues forever, unless one can escape. Different traditions have different roadmaps for this-known as liberation or mokșa. Liberation, as presented in the Viṣnu Purāna, is a merging with, or dissolution into, the Absolute, which is synonymous with the highest state of Viṣnu. This is achieved by those who cultivate the deepest devotion to the Divine and those who realise that the universe and all it holds are ultimately no different to the deity and indeed oneself. This perhaps constitutes the central theological message of our text.

Thus, the Viṣnu Purāna represents a joyous jumble of Vaiṣnava theologies from different periods and traditions: Viṣnu as the supreme deity, as the ineffable brabman or Absolute, as one of the 'purānic' trinity, the preserver of the universe and as the highest state of liberation from cyclical existence. 


\section{Viṣnu and Kṛ̣̣na}

Viṣnu also causes aspects (amśa) of himself to manifest in the universe. These are known as avatäras, as they have 'crossed down' into the world. The ten forms commonly listed are the fish, tortoise, boar, the demonslaying man-lion, the dwarf who paced out the universe in three strides, the murderous brahmin Paraśurāma, Rāma, the hero of his own epic, Kṛ̣na, who is arguably the hero of this epic, the Buddha (yes, the Buddha) and Kalki, the sword-wielding manifestation of the future, who will cleanse the world of evil. Earlier texts like the Mahäbhärata list four, six or eight avatāras, while a later source, the Bhägavata Purāna, which generally strives to outdo the Viṣnu Purāna, gives twenty-two.

By far the most important manifestation of Viṣnu in this purāṇa is Kṛ̣ṇa. Some scholarly authorities believe that Kṛnna was originally a minor local deity of herding people who was subsequently incorporated into the mainstream Hindu pantheon. In fact, the Viṣnu Purāna without Kṛ̣na is unthinkable, but the relationship between Viṣnu and Kṛ̣na is more complicated than one simply being the manifestation of the other. There seem to be three different relationships. For much of our text, Kṛnna simply is Viṣnu. They are one and the same entity and their names and epithets are used interchangeably-sometimes even within the same or consecutive verses. Second, Kṛ̣na appears as one among a number of manifestations of Viṣnu, as mentioned above, but is less than Viṣnu, being just a part or an aspect of the Divine. This is also a very common mode of representation in the Viṣnu Purāna.

At the start of Book Five, we learn that Krṣna appeared in the world as 'an aspect of Viṣnu's aspect' (amśämsenena; 5.1.3). This may be a reference to the fact that Visnu let two of his hairs, one black and one white, fall to earth, where they became Balarāma and Kṛ̣nna, respectively (5.1.61). Kṛ̣na is an aspect of the hair, which is itself an aspect of Viṣnu. We also discover that Kṛnna’s elder brother is an aspect of the divine serpent Śeșa. As that being is itself an aspect of Viṣnu, Balarāma is also said to be 'an aspect of an aspect' of the deity (5.1.73).

Book Five focuses almost exclusively on Kṛ̣na and is, in many ways, the most accessible, ardent and significant part of the Vișnu Purāna. Why it would seek to downgrade its central character in the opening verses is unclear. It is interesting to reflect on the fact that in later Vaiṣnava traditions, 
especially the Gaudīya sects originating from Bengal, Kṛ̣na totally eclipses Viṣnu. It is he who is the ultimate being, and Viṣnu is a mere manifestation of him, not vice versa, as in earlier sources. ${ }^{5}$

The irresistible cowherding youth, the adventurous lord of Dvārakā, as well as Arjuna's friend and confidant during the Mahābhārata war-these three different mythologies are tenuously linked with the name Kṛna, all of whom are the Divine incarnate. The academic impulse is to try to tease these skeins apart, but to a traditional audience and the faith community such an approach is irrelevant, as are the age and authorship of the text. Viṣnu is everything, everything is Viṣnu. The Viṣnu Purāna is poetry, beauty and nectar to be imbibed and relished. ${ }^{6}$

\section{The other avatäras}

Apart from Kṛṣna, most of the other avatāras are not particularly significant in the Viṣnu Purāna. We hear how, during creation, Viṣnu in the form of the boar raised the world from the bottom of the cosmic ocean on the tip of his tusk. The deity also manifested as Ràma, the hero of the Ràmāyaña, who defeats the demon Rāvaṇa, abductor of Rāma's wife, Sìtā. A potted version of the story of Rāma is included in the fourth book of the Vișnn Purāna (4.4.49-54). The fish avatära, we know from other sources, saves humanity from a cataclysmic flood that closely resembles the Biblical event, right down to the ark. When the gods sought to churn the nectar of immortality from the Ocean of Milk, Viṣnu manifested as a tortoise so the churning stick could rest on his back. In the form of a dwarf, he asked the demon king Bali for as much land as he could cover in three steps. Bali agreed, but the deity then assumed a giant cosmic form and 'paced out the threefold world with three heroic strides' (5.5.17). Viṣnu manifested as Paraśurāma, the irascible brahmin who repeatedly exterminated the entire class of warriors, the ksatriyas, as he believed they were abusing their power. The final avatära is yet to come. He is named Kalki, and we are told he will be imbued with 'eight qualities and perfections, greatness and irresistible power'. Kalki will sweep away all barbarians to reestablish virtue in the world, and those who wake 'when this night has passed, will be stainless, clear and pure' (4.24.20).

5 See also Matchett (2001).

6 For more on the nature of Viṣnu in the Viṣnu Purāna, see Adluri (2019). 
The role of the Buddha in the Visnu Purāna is a curious one. Many other sources maintain that the Buddha was an avatâra of Viṣnu. The Enlightened One appears in the Viṣnu Purāna not in this form, but as a phantom brought forth by the deity to confuse the demigods. In Book Three, the deities are locked in one of their never-ending battles with the demons and, at this point in the narrative, they seem to be losing. To assist them, Viṣnu creates a phantom (māyamoha), who teaches the demons thinly disguised religious dogma that closely resembles the teachings of Jainism and Buddhism. The demigods are seduced by these heretical ideas and abandon the true religion of the Vedas. Once the demigods are weakened in this way, the gods are able to regain the upper hand and overcome them, at least for the short term (3.17-18).

\section{The purānic thought-world}

The Viṣnu Purāna was created within a particular conceptual universe, its 'thought-world'. It reflects this universe and also serves to perpetuate it. The oldest stratum of the Vișnu Purāna's thought-world are the Vedas. The word veda means 'knowledge' and is related to words like 'wit', 'witness' and 'wisdom' in English. The Vedas are anthologies of songs of praise, largely devoted to elemental deities, such as Agni, god of fire, Sūrya, the sun god, Ușas, the goddess of dawn, and Vāyu, god of winds. The recurrent themes in the Vedas largely reflect the existential concerns of nomadic herding people: they need sun and rain to ensure good pasture, strong bulls to lead the herd, sons to perpetuate the family, victory in battle and protection from all sorts of night-ranging demons. No-one knows how old the Vedas are. The traditional view, such as that given in the Viṣnu Purana, is that they pre-date the universe. Current scholarly consensus holds that they date from at least 1,500 years before the current era. The evidence for this dating is wafer-thin and the Vedas could in fact be considerably older. In any case, they are the earliest surviving examples of Indo-European literature.

The most important Veda is the $R g$, the 'Veda of Verses'. It consists of just over 1,000 songs (a total of about 10,000 verses) arranged in 10 books according to the priestly family said to preserve them. ${ }^{7}$ The Sama Veda,

7 The easiest points of access to the $R g$ Veda are Doniger (1981) and the Introduction to Jamison and Brereton (2014). 
or 'Veda of Songs', has about 1,500 verses from the $R g$ Veda (one-sixth of the total), arranged either by the metre in which they are composed or by the deity to whom they are dedicated. Songs from the Sama Veda are chanted during rituals. There are several references to the sound of the Säma Veda in the Viṣnu Purāna. The Yajur Veda, or 'Veda of Formulae', contains nearly 2,000 verses. These are largely sacred utterances or mantras used during rituals. Sometimes a fourth, the Atharva Veda, is mentioned in connection with the other three. This anthology of 700 songs contains about 6,000 mantras, including spells to ward off disease, snakes and other evils, as well as prayers for health and welfare.

For our purposes, and throughout much of Indian history, the literary content of the Vedas is not as important as their symbolic value. They were composed in an early dialect of Sanskrit that is often difficult, and in some cases impossible, to understand. In practice, their power lies in their sound and, in literature, their usefulness lies in their potency as a symbol of authority, validity and antiquity. We see this in the way the Vedas are employed in the Viṣnu Purāna.

The Vedas were at the heart of a traditional brahminical education. A boy at the age of six was sent to live in the home of his guru-usually a male relative-and, as we see from the Viṣn Purāna, the student would be required to learn a certain number of Vedic and ancillary texts by heart. Even today, the family names Dvivedi, Trivedi and Chaturvedi indicate the number of Vedic texts- two, three or four-clan members are supposed to have mastered.

The Vedas have great creative potential. The creation of the universe is said to be ordained by these texts and carried out in accordance with their dictates. As the Vedas carry the highest possible symbolic value, the ultimate accolade is to call something 'the equal of the Vedas'. Thus, in the Viṣnu Purāna, the deity Viṣnu-Kṛnna is said to embody these texts or, more simply, to be the Vedas (1.4.22). Authors of Sanskrit texts often appropriate Vedic prestige to elevate their own words. For example, the Mabābhärata, Ràmàyana and the Bhägatava Purānas all refer to themselves as 'the fifth Veda'. Towards the end of the Viṣnu Purāna, the main narrator, Parāsara, claims that this text is also 'the equal of the Vedas' (6.8.12).

Conversely, the direst accusation one can make about a person is that he or she insults or disregards the Vedas. This is the most common accusation laid against 'heretics', which in the Viṣnu Purāna usually indicates adherents 
of non-Hindu traditions such as Buddhists, Jains and possibly Tantric practitioners. Dishonouring or selling the Vedas leads to a hell realm called Lavana, the 'Salty Hell' (2.6.13). As we have seen, to abandon the Vedic path of true religion will certainly lead to one's downfall.

The Vedas disappear from the world when it is destroyed at the end of each cosmic cycle. The deity then creates seven sages whose job it is to 'hear' the sound of the Vedas, which continue to reverberate and animate the cosmos, and to bring them down to earth again. Thus, Vedic texts are also known as śruti, 'that which is heard'. Each new age also has a Vyāsa, a sage who again divides the undifferentiated verses into their four anthologies.

These Vedic texts are used primarily in ritual, the most important of which is the sacrifice. There are two main kinds of sacrificial act. In one, the juice of an unidentified plant known as soma is offered into a fire or drunk. In the other, clarified butter or ghee is offered. As the oblations are made, relevant texts are recited and ritual cries of vașat, svadhā, svāha and om are made. There are several mentions of these cries in the Viṣnu Purāna. In these rituals, the oblation is carried to the gods by fire personified as Agni. We also read of the deities being invited to the sacrifice, where, seated on mats of sacred grass known as kusa, they receive their due portion of the offerings. The gods are nourished by the oblations and, if properly satisfied, provide rain. Rain of course enables all life to thrive and supplies the necessities for further sacrifices. Thus, the sacrifice, gods and humankind exist in a sort of circular symbiotic relationship.

The most extreme ritual is the Asvamedha or horse-sacrifice. This is said to be undertaken by a king to proclaim and consolidate his sovereignty. A consecrated horse is allowed to wander freely for a year, accompanied by an armed force. Any territory the horse traverses is claimed by the king. After a year, the horse is brought back and killed. Were Asvamedhas ever actually carried out or are they a literary fiction? While there are historical records of Asvamedhas being performed, it is hard to imagine that every particular detail would be followed; the queen, for example, is required to have sexual intercourse with the horse after it has been sacrificed. Whether Asvamedhas were real or not, they have a literary reality and are the ultimate source of religious merit. There are several references in the Viṣnu Purāna to events or practices that generate 'as much merit as an Asvamedha' or words to that effect. 
The idealised society of the brahminical imagination consists of four communities or orders-a system that first appeared in the most recent layer of the Vedas. The Sanskrit term for these communities is varna, meaning 'colour', and has historically been translated as 'caste' or 'class'. This system may reflect some social reality prevalent in Vedic times, but its relationship to reality in later periods is less clear. What is clear, however, is that varna remains a powerful and pervasive concept in the Viṣnu Purāna and, in various forms, continues to shape Hindu societies to this day.

The four orders are as follows: first, the brahmins or priestly community are chiefly responsible for ritual practice and performing the sacrifice. To do this, they must master the texts, and they live off the fees they receive for ritual practices they undertake on behalf of others. The ksatriyas are the warrior community and, in this idealised world, they furnish kings to rule the state. It is the duty of ksatriyas to wage war and to defend the realm and its population. The third community is that of the vaisyas, whose occupations include animal husbandry, trade and agriculture. These three orders are known as the 'twice-born', because sons in these communities undergo a second, spiritual, rebirth when they are initiated into a school of Vedic study and receive their sacred thread. Although sacrifice and ritual practice are the special duties of brahmins, members of all three twice-born communities are entitled to study the Vedas and perform sacrifices.

The fourth community is that of the siudras. This order is mentioned only briefly in the Vedas, and only in those sections thought to be more recent. By the time of the epics and purannas, the concept of an underclass of servants was firmly entrenched. The Viṣnu Purāna also allows members of this class to practice a trade or craft. They may undertake rituals for their own ancestors, but for any other rites they must engage members of other communities on their behalf. The Viṣnu Puraña declares not only that the system of four orders, the caturvarnya, is the natural structure of society in this world, but also that societies on the other six continents that make up the mythical purānicic universe are all structured on similar lines.

Another important concept that is fundamental to traditional brahminical dogma is the four stages of life (caturäśrama), through which all pious individuals, especially brahmins, are theoretically expected to pass. The first stage is that of the celibate student or brabmacarin. As mentioned, between the ages of six and eighteen, a boy is expected to live with his guru to receive his education. This consists of learning Sanskrit and mastering one or more branches of Vedic recitation and practice. At the completion 
of this phase, the student recompenses his teacher with a fee, the gurudaksin $\bar{a}$, and may then choose to marry. The young man then embarks on the second stage, the life of the householder (grhastha). In old age, the pious individual will leave his responsibilities with his sons and set out for the forest (vanaprastha). There he 'should live on leaves and roots and berries, his hair and beard and matted locks untended'. He is supposed to sleep on the ground and should welcome all comers as guests (3.9.19). During the fourth and final stage, that of the wandering ascetic (samyasin), the devotee abandons the forest and lives with no fixed abode: 'He'll stay in a village for just one night, or in a city for five, lest he start to like or loathe them', begging food as he goes (3.9.28). Certainly, the first two stages were adhered to in premodern times and are still today. The third and fourth stages remain powerful ideals, even if rarely followed.

In addition to the stages of life, another important concept in the purānic thought-world are the goals of human existence (purusärtha). The first of these is love or desire (kamma), especially in a physical sense. The second is wealth or material wellbeing (artha), in the sense that human life has certain physical requirements that need to be met. The third is dharma, which I usually translate as virtue, but which also carries the sense of correct conduct, especially in relation to the responsibilities of one's community and stage of life. More broadly, it has the senses of religion or spiritual life and practice. These three are often spoken of, but sometimes a fourthliberation from cyclical existence or moksa -is added.

The Vișnu Purāna contains an inherently conservative social message that seeks to preserve the community structure described above. Punishments are prescribed for individuals who neglect or stray from the duties of their community. On the other hand, sticking to one's communal role, as we are frequently reminded, is one of the ways a devout individual will be rewarded with heaven or liberation.

\section{Divine and semi-divine beings}

The purānic thought-world includes a rich ecosystem of supernatural beings. At the apex are the deities or gods known as suras or devas. These are in general the old Vedic deities led by their king, Indra, and include the creator, Brahmā, the 'grandsire of the world'; the generally destructive and unruly Siva-Rudra; the heavenly twins known as the Aśvins; Varuna, god of oceans and waters; as well as the Agnis and Maruts, gods of fire and 
winds, respectively. A group of deities were the sons of a sage called Kaśyapa and his wife and are called Ādityas after her. Other frequently mentioned deities include the Sun, Moon and Earth and several undifferentiated hosts of gods known as the Viśvadevas, Vasus and Sādhyas. In the Viṣnnu Purāna, there are many mentions of the 'thirteen great deities' of whom Indra is the head, but the precise membership of this list varies. Many of these deities are said to have Indo-European precursors and may be 'related' to the gods of Greece and Rome.

The sage Kaśyapa, from whom the gods were descended, had another wife, Diti. She gave birth to the demonic demigods known as the Daityas. The Daityas are often mentioned in the same breath as the Dānavas, the offspring of Danu, another of Kaśyapa's wives. These two tribes of halfbrothers-asuras or 'not-gods' - never got on with the suras and are locked in an eternal struggle with them for sovereignty over the universe. Usually the demigods seem to have the upper hand, and the gods are often reduced to seeking assistance from Viṣnu. They supplicate the supreme being with effusive praise and he agrees to assist them. Granted some divine boon, the gods are thereby able to win the immediate battle, but the eternal war between good and evil drags on forever.

The demigods are in general much more interesting than their godly brothers. They are 'deceitful, ignorant, impatient and unrestrained' (3.17.18). They rage and fume, curse and swear, which makes their diction all the more lively. Demigods occasionally appear in the world of mortals. They all have supernatural powers, such as the ability to fly through the air and change shape at will. Most notable among the Daityas is the king Hiranyakaśipu, who had terrible trouble with his son Prahlāda. This demon lad betrayed his demonic roots and became enamoured of the divine ideology of Viṣnu, his father's nemesis (1.15-20).

There are several other species of less-important semi-divine beings. Siddhas are highly accomplished saints or sages who have acquired supernatural powers. They do not have much to do in our text but turn up occasionally to sing the praises of Viṣnu-Kṛnna. Gandharvas are described in many sources as 'celestial musicians'. The Viṣnn Purāna questionably claims that their name arises from the fact that they were born 'drinking speech' (1.5.46). They are handsome and, like the siddhas, their main function in our text is to sing the praises of the deity. 
Apsarases are hosts of semi-divine female beings with supernatural powers and irresistible charms. If a deity ever needs to distract a sage from his meditation, he usually sends one of these beautiful females to do the job. Apart from seducing sages, the main role for apsarases in our text is to sing and dance in honour of the deities.

Nägas are semi-divine serpent spirits that are neither particularly benevolent nor malevolent. We know from visual art that they resemble humans from the waist up, with a snake's body and tail from the waist down. Among the most famous nāgas are Śeșa, the benign many-headed serpent who forms a couch for Viṣnu to recline on, and venomous Kāliya, whom Kṛ̣na defeats in battle. Nägas reside either in the waters or in the lower realms, where, like other Indo-European dragons to whom they are probably related, they hoard treasure. In our text, nāgas are described as 'fork-tongued, resilient, cruel and bent on pleasure' (3.17.23).

Supernatural yaksas are generally innocuous but somewhat shadowy in the Viṣnu Purāna. They have frivolous hearts, lack discernment and hanker after sensual pleasures (3.17.19). Our text offers a fanciful etymology, claiming that they are named because of their desire for food (jaksana; 1.5.43). In other Sanskrit literature-notably Kālidāsa's courtly poem Meghadüta - they are the attendants of Kubera, god of wealth.

Among the more malevolent beings are räkșasas, gubyakas and paisáacasall hideous night-ranging demons who feed on human flesh. Parāśara, the narrator of the Viṣnu Purāna, should know about these, as his own father was eaten by one. Described as 'cruel, deceptive, fierce and dark' (3.17.20), they continually strive to disrupt the sacrifices conducted by sages, in order to weaken the gods.

There are several other species of semi-divine being-some good and others bad-in the Viṣnu Purāna, but they are usually mentioned only in lists and play no active role in the narrative. These include celestial musicians known as cāranas and vidyādharas, and kimnaras and kimpurusas (both of which literally mean 'What kind of person?!') and disease-causing spirits known as kūsmañ das. 


\section{Elements of the Viṣnu Purāna}

\section{Overall frame}

The Viṣnu Purāna is framed simply as a dialogue between two legendary sages, Parāsara and his disciple Maitreya. This in itself distinguishes the Viṣnu Purāna from most other purānas and the epics, which have much more complex framing structures. Typically, the primary storyteller is a wandering seer, such as Lomaharsana or Ugraśravas, who arrives at the Naimișa forest, where he narrates the story to the assembled sages led by Śaunaka. The narrator's story may be a direct account, but more often it is the repetition of another story told by a third or even a fourth party.

Parāsara explains to Maitreya that the Viṣnu Purāna was first related by the original creator deity, Brahmā, grandsire of the world. From Brahmā, the narrative was passed orally from one listener to another. The lineage as recounted in the Viṣnu Purāna consists of about twenty figures and includes divine sages, various semi-divine serpents, a river goddess and some residents of the underworld, before it finally reaches Parāsara, who relays the text in full to his inquisitive disciple.

Both Parāśara and Maitreya are prominent figures elsewhere in Sanskrit literature. Parāsara was the grandson of Vasisțha, one of the original Seven Seers who are present at the beginning of every era, and domestic chaplain to Rāma and the Solar Dynasty. Parāśara is said to be the disciple of the great law-giver, Yājñavalkya, and was the Veda-vyāsa, or 'arranger of the Vedas', in a previous age. Parāsara's son Vyāsa, who arranged the Vedas in the 'current' age, was also the composer and transmitter of many seminal texts, including the Mahābhārata and many of the purānas. Parāśara himself appears as a character in the Mahäbhärata as the great-grandfather of both the Kauravas and the Pāndavas, the two warring families of cousins whose conflict lies at the heart of the epic. Another of Parāsara's grandsons (also through Vyāsa) was the naked sage Śuka, who recited the later Vaiṣnava classic, the Bhāgavata Purāna. Thus, Parāśara and his lineage are associated with three of the most important genres of Sanskrit literature: Vedas, purānas and the epics.

Like his guru, Maitreya is a significant stock character in the intertextual network that unites many threads of the Sanskritic literary imagination. Maitreya appears as a fully fledged sage in the Mahäbhärata, where 
he attempts to persuade the warring parties to make peace. After the cataclysmic war has finished, and while wandering the depopulated world, Maitreya comes upon Vidura, another prominent figure. Maitreya teaches Vidura about the world and the nature of reality. This discourse constitutes an important section of the Bhägavata Purāna mentioned above.

The dialogue between Parāśara and Maitreya, which constitutes the Viṣnu Purāna, takes place in deep mythological time. At one point, Parāsara mentions that the 'current' ruling monarch is the king named Parikṣit (4.20.13). This character was the grandson of Arjuna, one of the five Pāndava brothers, the heroes of the Mahäbhärata, and one of the few to survive the war. We know that Parāśara delivered this discourse long after Arjuna's demise. This same king Parikṣit is said to have listened to the Bhägavata Purāna on his deathbed. Thus, the Viṣnu Purāna is positioned in mythological time after the Mahäbhärata and before the Bhägavata Purāna and is fixed firmly between these two great classics of the Sanskrit archive.

Each of the Viṣnu Purāna's six books and many intermediate sections begin with Maitreya asking questions: What is the nature of the world? How did the gods and other beings arise? Who are the Manus? And so on. When his guru has answered in full, Maitreya usually replies, 'You have told me everything I asked about, now tell me about this', and initiates a fresh topic. This dialogic structure provides a clear framework for the narrative. It breaks the flow into manageable units and serves to focus the audience's attention on the matter in hand. It also provides some narrative tension that draws the account forward.

Parāśara includes many subnarratives in his answers to Maitreya's questions. As early as the second chapter of the first book, for example, he recounts a story that his grandfather, Vasișțha, had once told him. The Viṣnu Purāna is mercifully free of the complex, multiple embedded narratives that are common in other purānas and other genres. Texts such as the epics and fable literature $(k a t h \bar{a})$ often have many levels of narrative framing: stories within stories within stories-up to five layers deep in the case of the Pañcatantra (Taylor 2007: 28). The overall structure of the Viṣnu Purāna is relatively simple, reaching a maximum of three layers of narrative. At its most complex, Parāśara tells Maitreya the story of 'Foolish' Bharata, in which Bharata quotes the sage R.bhu lecturing Nidāgha on the subject of the highest truth (2.13-16). Elsewhere, Parāśara tells a story about how Bhīṣma recounted an episode he heard from a brahmin from Kalinga. 
That brahmin heard the story from a certain sage who could remember his death at the end of a previous lifetime (3.7). All in all, the dialogic structure of the Viṣnu Purāna remains relatively easy to follow.

About 80 per cent of the Viṣnu Purāna is written in verse, and the great bulk of this is in a metre called Anustububh, consisting of four half-lines of eight syllables each. Within each half-line, the rhythm of short and long syllables is generally maintained. Anusțubh is the 'vanilla' standard for Sanskrit narrative, epic and purānic literature. The fact that so much is composed in verse reminds us that it is to be chanted or, better still, sung. That is the reason I chose the medium of blank verse to translate the Sanskrit Anușțubhs of the Viṣnu Purāna and have tried to maintain a certain rhythm where appropriate in acknowledgement of the nature of the root text.

The remaining 20 per cent of the Viṣnu Puraña-almost the whole of the fourth book-is written in prose. Why is this? This book, which describes the lineages and deeds of the legendary Solar and Lunar dynasties, contains many genealogical lists. There are similar lists in other parts of the text in verse, so it cannot be argued that prose is better suited to genealogy. Similarly, the narrative sections of Book Four, as opposed to the genealogical passages, are not essentially different from narratives in other parts of the Viṣnu Purāna. Perhaps the answer lies in the fact that, to put it politely, the purannas are highly intertextual. Put less politely, some sections appear to have been cobbled together from other sources. Was Book Four included using a simple 'cut and paste' process from some other prose text? A quick search for passages similar to random samples from this book failed to reveal identical text elsewhere, but a systematic survey might provide more insights. I have translated the Viṣnu Purāna's Sanskrit prose passages into English prose.

If the form of the Viṣnu Purāna is a combination of verse and prose, we can think of its content as being of four kinds: narratives, genealogies, songs of praise and didactic material. The narratives are the raison d'être for any purāna, because, as mentioned above, the word purāna itself suggests 'tales of ancient times' or, perhaps, 'ancient accounts'. Narratives form the backbone of the text and cover the five themes that define the genre: the creation of the world, its subsequent re-creation, the origin of the gods and sages, the Manus and their reigns as well as the deeds of the kings of the Solar and Lunar dynasties. 
But what is the function of the long genealogical lists found throughout the Viṣnu Purāna? For the reader of an English translation they may not be the most edifying or enjoyable reading experience, as they closely resemble the 'He begat ... He begat ...' passages of the Old Testament. I suggest they fulfil four functions. First, genealogies of both legendary 'human' lineages, the Solar and Lunar dynasties, begin with Brahmā, the original creator deity. This divine origin ultimately lends sanctity and authority to every member of the lineage. In this sense, the genealogical lists provide legitimacy. Second, the lists demonstrate, for anyone with sufficient detective skills, the relationship between every significant character in the purānic thought-world. Third, they provide the logical framework for the narratives. Much of the Viṣnu Purāna is in mythical 'chronological' order. When a genealogical list reaches a significant character, the authors press 'pause' and insert narratives relevant to that individual. The fourth possible function of these passages is that they offer an opportunity for the accumulation of merit. This aspect is suggested in part by contemporary oral performance of purānic discourse. In these events, the simple act of hearing the words is regarded as meritorious (Taylor 2016). This idea is backed up by the Viṣnu Purāna itself when Parāśara instructs his disciple:

As the saying goes, 'The lineage of one who reflects each day on Manu's family, which descends from Brahmā, is never broken.' You should therefore listen to this lineage from start to finish, Maitreya, as it will wash away all sins. (4.1.4-5)

In addition to the narratives and genealogical material, the Viṣnu Purāna includes more than twenty songs of praise of the deity. These are known as stotra or stuti in Sanskrit and are one of the most important features of the Viṣnu Purāna and other works of Vaiṣnava Bhakti literature. These stutis share a number of prominent themes: Viṣnu is the creator, preserver and destroyer of the universe; he is without beginning or end; he is free from all qualities and pervades all creation. He is the Absolute, the highest state and purusottama, the supreme spirit. He abides within all beings, including gods, mortals, plants and animals. These songs are sung by a wide variety of characters, including the Earth herself, other deities, sages, humans and even the outstanding demon Prahlāda. In contemporary performance of the Bhägavata Purāna, these songs of praise are regarded as the most important elements of the discourse (Taylor 2016: 85), and it is easy to imagine this was the case in oral performance of the Viṣnu Purạna in premodern times. 
The didactic material-largely confined to the third book, 'Society'—deals with the details and practicalities of day-to-day life, from birth to death and everything in between, dwelling in considerable detail on the performance of śräddha offerings to nourish one's immediate ancestors. I will return to this in the summary of Book Three below.

As indicated above, the organisation of the Viṣnu Purāna is largely 'chronological', beginning with the creation of the world, running through to the 'present', but also looking forward to the future when the world will come to an end. That is not to say the whole text flows smoothly, as there are several discontinuities in the narrative. Examples are Parāsara's praise of Lakșmi (1.8.16-34), a hymn to the syllable $O m(3.3 .22-31)$ and especially the story of how Kṛṣna won the Syamantaka jewel (4.13). Chapters Five to Seven in the sixth book, 'Dissolution', which present a debate about the relative benefits of yoga and sacrifice, seem to have been tacked on to the end of the text. It is impossible to say whether this is what some putative 'original' creator of the text intended or whether later scholars or scribes added these passages. In any case, from a stylistic and narrative point of view, these sections present noticeable discontinuities.

\section{The six books}

\section{Book One: Creation}

Book One describes the creation and peopling of the world. Parāsara first tells Maitreya how his own father was eaten by a rākșasa and how he subsequently acquired knowledge of this purāṇa. He describes how Viṣnu created the world out of emptiness by agitating spirit and matter, and how the elements and senses combine to form the cosmic egg that contains the whole universe. Chapter Two includes a difficult abstract passage on the interaction of the cosmogonic properties known as the Seen (vyakta) and Unseen (avyakta), Individuation (ahamkāra) and Greatness (mahat). Parāsara interrupts his account of creation to describe the units of time, which range from one nimesa or blink of the eye, to one para, the lifespan of the deity Brahmā. In the form of a boar, Viṣnu catches the earth on the tip of his tusk and raises it from the floor of the cosmic ocean, to the delight of the onlooking sages. The earth is then divided into seven continents and is filled with plants, animals and humankind in four communities. 
People build houses and raise crops, and the first patriarchs and a legendary ruler known as Manu populate the earth. The irascible sage Durvāsas curses the gods, who then churn the Ocean of Milk to win the nectar of immortality. The princeling Dhruva is elevated to become the Pole Star through his devotion to Viṣnu. King Pṛthu is born from the hand of his dead father. Sages praise the deity from the bottom of the ocean. A stunning apsaras seduces an unsuspecting yogi and a girl is born from drops of sweat. Prahlāda, the son of the demon king, becomes a devotee of Viṣnu and undergoes terrible tortures, but sticks to his beliefs and finally achieves liberation. We are reminded by Parāsara that Viṣnu is brabman, the ineffable Absolute.

\section{Book Two: The World}

This book falls into two parts, the first of which deals with what we might call geography and astronomy. The world within the cosmic egg consists of the middle realm, which constitutes 'our' world, with lower realms below us and other realms above. This middle realm includes seven continents in the form of concentric rings, with each successive ring being twice as wide as the one within it. The seven continents are poetically named RoseApple, Pipal, Cottonwood, Kusa-Grass, Crane, Teak and Banyan. They are separated by oceans of saltwater, syrup, wine, ghee, whey, milk and freshwater, respectively.

Each continent is divided into seven regions by seven mountain ranges and is watered by seven major rivers. Every land has one sovereign with seven sons, each of whom rules a region. A society of four communities-not coincidentally analogous to the four orders in 'our' world-inhabits each continent. The central continent, Rose-Apple or Jambüdvīpa, has the cosmic Mount Meru at its centre. One of Jambūdvīpa's regions, Bhāratanamed after its regent, Bharata-is now known as India. The Viṣnu Purāna says: 'More fortunate than the gods are those who live in Bhārata, the land that leads to heaven and beyond' (2.3.24), as this is the only region where sacrifice, the precursor to liberation, is possible.

Below us are seven realms inhabited by Dānavas, Daityas and nāgas, which are even more splendid than those above. But below them lie twenty-eight hell realms, each with its own exquisite tortures. All classes of sinners are catered for: those whose crimes range from killing their guru to starting dinner before their father, selling cochineal or feeding cats. Special hells are 
reserved for actors, fishermen and vandals who upset beehives. Students of religious studies who ejaculate while napping are in for a torrid time. Fortunately, meditation on Viṣnu is prescribed as the atonement for all these crimes.

Above us are the upper realms, including the orbits of the sun, moon, planets and seven higher spheres. A challenging technical passage on the apparent annual movement of the sun and calendrical science is followed by a more readable chapter about rain.

The second half of this book, consisting of four chapters, contains a philosophical narrative delivered by the wise fool Bharata (no relation to the king of the same name above). This Bharata teaches the king of Sauvira about the nature of reality, in which he recounts a snappy and amusing dialogue between two sages, R.bhu and Nidāgha.

\section{Book Three: Society}

This book is largely about the Vedas, their origin, arrangement, rituals and efficacy. The first few chapters describe the Manus, the legendary rulers who reign over vast intervals of cosmic time called Manvantaras or Manuperiods. Six Manus have already passed. We are in the period of the seventh, Vaivasvata, and there are seven more to come. In addition to its own Manu, each Manvantara has its own set of deities and seven sages who will 'hear' the Vedas anew. The fourteen Manus reign for a total of one thousand cycles of four ages-Kṛta, Tretā, Dvāpara and Kali-which together make one aeon or kalpa. In every Dvāpara age, a Veda-vyāsa (literally, a 'Vedaarranger') appears to divide the primeval and ever-existent Veda into four parts. Each of the four Vedas is further split into branches that are entrusted to various sages.

In Chapter Seven, Maitreya asks how one may escape hell. The answer is given in a lively dialogue in which Yama, the lord of death, instructs his servants to ignore the pious devotees of Viṣnu when collecting souls for punishment. The rest of this book describes various Vedic life rituals pertaining to birth, marriage, daily practices, conduct in the bedroom, death and sacrifices for the ancestors known as śräddha. Nine chapters (Eight to Sixteen) are in the form of an embedded dialogue between the sages Aurva and Sagara. 
Book Three includes sections on how to choose a wife and name a son. Chapter Eleven describes a day in the life of a brahmin gentleman, and Chapter Twelve provides dos and don'ts for the wise, including such good advice as, 'Avoid animals with tusks and horns' and 'Don't blow your nose at mealtimes'.

This book ends with an episode in which Viṣnu creates a phantom. This being closely resembles, first, a Jain ascetic and, then, a Buddhist monk, to trick the demigods into abandoning the Vedas. Once the demigods have strayed from the path of true religion, the gods easily defeat them. This last section offers a glimpse into the types of religious debates and tensions that may have been experienced during the period of the Viṣnu Purāna's development.

\section{Book Four: The Royal Dynasties}

The fourth book is largely 'historical', as it describes the kings of the Solar and Lunar dynasties. This topic, like the description of the Manvantaras in Book Three, is one of the five themes, or pañca-laksana, that define a purāna. Book Four represents a significant change of pace as it is nearly all in prose, except for several embedded songs of praise and verses quoted from other sources. It is worth reading this book carefully, even the long genealogical lists, as doing so will 'wash away all misdeeds', we are assured.

After the creator deity Brahmā arose from the cosmic egg, the patriarch, Dakșa, was born from his right thumb. Dakșa's daughter was Aditi, who gave birth to the Sun. The Solar Dynasty begins with the son of the Sun, Manu Vaivasvata. This book detours through many subnarratives as it describes the Solar lineage, including many folk etymologies to explain the origins of various names. We read of King Yuvanāśva, the man who gave birth to a son. The sage Saubhari lived underwater, where he made friends with a fish but abandoned his vows to have children. Sagara's sixty thousand sons excavated the ocean while searching for a missing horse. A king named Kalmāṣapāda, like a modern vampire, turned into a rākașasa and dined on human flesh at night. This section includes the legend of King Nimi, which explains why all animals blink.

Included in the Solar Dynasty is Rāma, hero of the Rammàyana, whose story appears here in highly abbreviated form. Vālmīki’s hegemonic version of the epic ends with Rāma's consort Sìtā in miserable exile and her return to Mother Earth. The Viṣnu Purāna's potted version, by contrast, 
concludes on a happy note, with Sītā safely lodged in Ayodhyā. This raises the interesting possibility that this section of the Viṣnu Purāna may have been composed before Vālmīki's orthodox and anticlimactic narrative swamped most other versions.

Like the Solar Dynasty, the Lunar Dynasty also originated with Brahmā. This deity had a son, Atri, whose son was Soma, the Moon personified. Soma's first son, Budha (no relation to the Buddha with two ds), was abandoned in a reedbed, just like Moses of the Old Testament. This section also contains dozens of iconic subnarratives: King Purūravas's ill-starred affair with an apsaras who kept two pet sheep in her bedroom; King Jahnu, who drank the Gangā River dry; a mother-and-daughter pair who swapped bowls of magic porridge; King Raji, who did a deal with deities and won sovereignty over the gods; and Yayāti, who convinced his son to trade his youthfulness for his own old age. Chapter Thirteen includes the strange and somewhat inconsequential narrative of how Kṛnna acquired the magnificent Syamantaka jewel. As mentioned above, this story seems out of place as it recounts this famous episode in the life of Kṛ̣na, even though we do not reach his birth until a later chapter.

Book Four includes the ancestors of the Pāndavas and Kauravas, the heroes of the Mahābhärata, and their descendants, including King Parìkṣit, 'who rules all the world today in accord with virtue' (4.20.13). Parāśara names the kings who will rule in future and foretells the existence of some of India's well-known early dynasties, including the Mauryas, Sungas and Guptas. This is as close to verifiable history as the Viṣnu Purāna gets. As the last-named dynasty ruled until the middle of the sixth century CE, we may assume that this passage of the Viṣnu Purāna was composed during or after the Gupta Empire.

The age of Kali will come to an end with these lineages, and the Viṣnu Purāna gives a damning description of this period of decadence. Parāśara closes the book with a pithy observation on the futility of human endeavour and the mercilessness of time: 'Bhagiratha, Sagara, Kakutstha and Rāvana, Rāma, Lakșmaṇa, Yudhișțhira and the others-there's no doubt they all existed, but where are they now? We just don't know' (4.24.68). 


\section{Book Five: Kṛ̣ṇa}

Book Five is really the heart of the Viṣnu Purāna, as, in the broadest sense, the preceding four books have all been building towards this climax: the advent, exploits and eventual withdrawal of Viṣnu's manifestation in the form of Krṣna. The book opens in the city of Mathurā with the wedding of Kṛna’'s parents, Vasudeva and Devakī. This happy event is spoiled when a disembodied voice from the heavens warns Kamsa, the king of Mathurā, that Devakî's eighth child will eventually destroy him. The king keeps the couple under lock and key for years and murders each infant as it is born. Vasudeva, with divine intervention, smuggles the eighth baby, Kṛ̣na, out of the city and delivers him to the cattle-herders' camp across the river. There he places the baby in the bed of Yaśodā, the head herder's wife.

Kṛṣna and his elder brother Balarāma enjoy a bucolic childhood in the camp, and exhibit prodigies such as overturning a fully laden wagon and uprooting two huge arjuna trees. Kamsa sends a succession of demons to kill Kṛ̣na, including the ogress Pūtanā, and others in the forms of a donkey, a bull and a horse. This book includes many other well-known episodes, such as the subjugation of the serpent Kàliya, the raising of Mount Govardhana and Kṛnna’s lovemaking with the cowherding girls. It includes a delightful episode in which the girls, playing detective, discover Kṛ̣na’s lovemaking by interpreting his footprints on the sandy forest floor (5.13).

Now a young adult, Kṛṣna leaves the cattle camp for the nearby city of Mathurā, where his adventures continue. He confronts and kills his nemesis, Kamssa, and becomes the leader of the Yãdava clan. Kṛṣna leads his people across India to establish a new capital at Dvārakā in the west. He abducts and marries Rukminī, and sires a vast tribe, the foremost of whom are his son Pradyumna and grandson Aniruddha, whose exploits are described. In accordance with a brahmin's curse, the Yâdava clansmen eventually fall on one another in a murderous spree, leaving Kṛsna alone alive. One day he is reclining in the forest when a passing hunter mistakes his foot for a deer and shoots him with an arrow. Thus, Viṣnu's manifestation as Kṛ̣na and Book Five draw to a close.

\section{Book Six: Dissolution}

Just as the Viṣnu Puranna begins with the creation of the world, it now concludes with its multiple forms of dissolution. While the text states explicitly that there are three types of destruction-causal, elemental and 
final-it actually begins with another, the destruction that takes place at the end of each Kali age. It prefaces this with a description of this decadent time itself, some aspects of which may be disturbingly familiar. At the end of the age of Kali, the world is destroyed, only to be recreated in the Krta, and the cycle of four ages begins again.

The second type of cosmic destruction, causal dissolution, takes place at the end of each aeon or kalpa, which consists of one thousand cycles of four ages, or 4.32 billion years. The world is then consumed by fire, which is extinguished by a cosmic deluge leaving nothing but a vast ocean on which the deity rests until the universe is created again.

A kalpa is but a single day for the deity Brahmā, who is said to live for one hundred of his own years, after which the elemental dissolution of the world takes place. The very elements from which the universe is composed-earth, air, fire, water and space-are reabsorbed into the Absolute in this process.

The so-called final form of destruction is a hybrid of this concept of cosmic destruction and the idea of liberation from cyclical existence. Liberated beings achieve a state of union with the Divine and are never reborn. The Viṣnu Puranna seeks to convince us of the desirability of this state with a gruelling description of the horrors of birth, life and death. The antidote to existential suffering and the means of achieving this final dissolution is total surrender to the deity, which, after all, is the Viṣnu Purāna's takehome message.

The latter part of Book Six offers a reflection on an age-old debate in Hindu traditions: is it better to seek perfection through ascetic practices such as yoga or social practices that include the Vedic sacrifice? This illfitting and anticlimactic appendix compares the twin paths known as pravrtti and nivrtti. The contest is put into the mouths of two kings, Khāṇ̣ikya and his cousin Keśidhvaja. With this, the Viṣnu Purāna limps towards a conclusion.

Like many major Sanskrit texts, the Viṣnu Purāna finishes with a section called the phalas'ruti, the 'fruits of listening'. Anyone who hears this narrative with devotion, recites it or calls it to mind will be freed from all their sins, we are promised. 


\section{The Sanskrit text}

The master list of Indian manuscripts, the New Catalogus Catalogorum of the University of Madras, lists about two hundred and seventy-five manuscripts of the Vișnu Purāna in public and private libraries all over India and elsewhere, which suggests that this was a relatively popular and widely dispersed text in premodern times (Pathak 1997-99: Vol.1, p.13).

Of the earlier printed editions of the Vişnu Purāna, the version edited by Rajendranatha Sharma and published by Nag Publishers in 1985 is relatively accessible (Sharma 1985). This version includes two commentaries, the Viṣnucittīya of Viṣnucitta ( twelfth century CE) and the Ātmaprakāśa of Śrīdhara (thirteenth to fourteenth century CE). These commentaries are said to be given from the perspectives of Viśișțādvaita and Advaita Vedānta, respectively (Adluri 2019). Both are sometimes useful for unravelling otherwise obscure passages of the root text, but I am often reminded of the words of my colleague Barbara Nelson, who wryly observed that commentators tell you what you already know, but not what you want to know.

This is a translation of the critically reconstituted text of the Viṣu Purana edited by M.M. Pathak of the Oriental Institute at the Maharaja Sayajirao University of Baroda in Vadodara, India. This edition was published by the university in two volumes (Pathak 1997-99). In Indological circles, a critical edition is usually taken to be the earliest version of a text from which all consulted manuscripts are ultimately derived. This is of course different from the 'original' text, if such a thing ever existed. A critical edition might also be regarded as a new version, based on selected manuscripts, subject to the personal preferences of the editorial team. The Baroda critical edition consists of the final edited text in Devanāgarī script at the top of each page, with the variations found in each manuscript (the 'critical apparatus') presented in fine print below. This allows an overview and comparison of all the manuscripts selected for the project.

Researchers preparing this critical edition consulted forty-three manuscripts, which they divided into two groups based on script. The northern group was written in Śāradā, Newārī, Maithilī, Bengāalī and Devanāgarī, and the southern group in Telegu, Grantha and Malayālam scripts (Pathak 1997-99: Vol.1, pp.1-2). The team found considerable agreement among manuscripts from widely separated geographical areas. The broad range of manuscripts suggests that the Viṣnu Purāna was known 
and valued through much of the Indic world, from Kashmir and Nepal in the north to Kerala and Tamil Nadu in the south. Most manuscripts are undated. The earliest is in Devanāgari script and dates from about $1207 \mathrm{CE}$. The other five dated manuscripts are from the sixteenth to the eighteenth centuries CE (Pathak 1997-99: Vol.1, p.14).

\section{Other translations}

There are already several translations of the Viṣnu Purāna, undertaken over the past two centuries. The first was by the pioneering British Orientalist Horace Hayman Wilson (1786-1860). This was originally published in 1840 in five volumes under the title The Vishniu Purana: A System of Hindu Mythology and Tradition (Wilson 1961). A second edition, which appeared in 1880, has since been reprinted in India a number of times. Wilson's was one of the first English translations of any purānic text, and it became an important source of information on Hindu traditions in the West at that time.

Wilson based his translation on 'a collection of various manuscripts in his possession'; a total of seven was consulted (Wilson 1961: lxxi). In general, it appears that the manuscripts he consulted differed only in minor details from the reconstituted Baroda text. Wilson's translation is generally accurate and his scholarly footnotes useful. His diction is lofty, chaste and antiquated. He omits most if not all of the epithets that Sanskrit authors use for metrical reasons, and he wrote before the current system of scholarly diacritics for Sanskrit words was established. ${ }^{8}$

Nearly twenty years after Wilson's second edition, M.N. Dutt, rector of the Keshub Academy, a high school in Calcutta, published a new version of the Vișnu Purāna (Dutt 1896). This version-simply a recasting of Wilson's translation-is in some senses more modern, as it uses many Sanskrit terms, which by that time would have been familiar to an Indian readership. In other ways, it is more archaic, as Dutt uses an anachronistic register filled with King James-isms, such as 'thee' and 'thy', in contrast with Wilson's 'you' and 'your'.

8 Madame H.P. Blavatsky, the co-founder of the Theosophical Society, made over a hundred references to Wilson's translation in her Secret Doctrine, a classic of high-Victorian occultism published in 1888 (Jansma 1999). 
A bilingual Sanskrit-Hindi edition of the Viṣnu Purāna was published in 1967 (Gupta 1967). The two languages are presented side by side on each page in columns, which facilitates comparison of the Hindi translation with the root text. I occasionally found this translation helpful for analysing complex compounds or clarifying certain points of grammar. It was less helpful when it came to understanding difficult Sanskrit terms, as the translator often simply repeated the original Sanskrit terms in grammatically correct Hindi sentences.

The only other recent translation of the Viṣnu Purāna of which I am aware was undertaken by Peter Schreiner of the University of Zürich, under the title Viṣnupurāna: Althergebrachte Kunde über Viṣnu ('Viṣnu Purāna: Traditional Lore about Viṣnu') (Schreiner 2013). This reliable and scholarly German prose translation makes good, clear sense of difficult passages in the original and was of great assistance to me. Schreiner includes a comprehensive commentary and a complete index of proper names. Some Sanskritists will be perplexed by the fact that Schreiner elected to translate some Sanskrit names into German-thus, the well-known demon king Hiranyakaśipu appears as ‘Goldpolster' or 'Golden Cushion' in English.

\section{About this translation}

My friend and colleague Simon Brodbeck of the University of Cardiff has recently published a translation of the Harivamsa, entitled Krishna's Lineage (Brodbeck 2019). Dipping into early drafts of Simon's book, I suddenly felt that I was reading for the first time a truly modern translation of a Sanskrit text. As another colleague noted, it was easy to forget that one was actually reading a translation at all. The author has achieved a laudable balance between clear contemporary diction and a timeless dignity that has inspired and informed my own approach to the Viṣnu Purāna. I have attempted to balance the requirements of creating a contemporary translation that is readily accessible to modern readers with the need to retain something of the gravity that befits a text like the Viṣnu Purāna, which is, after all, 1,500 years old.

'Poetry is what gets lost in translation': this useful definition applies of course to the Viṣnu Purāna, as well as to any other text. The greater part of the Viṣnu Puranna-five out of its six books-is written in verse and is meant to be recited, chanted or sung. How, then, can one best render Sanskrit poetry into a suitable form of English for a general readership? 
Here, I would like to acknowledge Carole Satyamurti's Mababharata: A Modern Retelling (2015). As it is a free transcreation of the epic in blank verse, rather than a translation in the conventional sense, the author was not tied by strict fidelity to the root text, but enjoyed the freedom to create beautiful, natural and rhythmic iambic pentameter.

Although necessarily constrained by the demands of translation, I have tried to create a text with some poetic sensibility in English, one that honours and respects both the sense and the rhythmic properties of the root text, without doing violence to the meaning of the original or to English syntax. I hope-perhaps vainly-that just as the Sanskrit verses of the Viṣnu Purana are pleasant to the ear when read aloud, readers might also find pleasure in the sonic and rhythmic properties of this translation.

While poetic, the Viṣnn Purāna is written in workaday purāṇic Sanskrit-a literary style it shares with the epics, the Mabäbbärata and the Ramayana. This is quite distinct from the elaborate courtly style of the later Bhägavata Purāna or other poetic works known as kāvya. As the Sanskrit diction of the Viṣnu Puraña is relatively simple, I have tried to avoid translations that sound bombastic, overly classical, archaic or Jacobean, in general favouring a simple Anglo-Saxon register over a Latinate one. This became more difficult when translating the effusive songs of praise, the stutis, in which devotees pour out unbroken streams of emotion at an almost ecstatic fever pitch.

The Viṣnu Purạna is not without internal contradictions and confusion. To provide clarity, I have used two approaches. In some cases, I have added a few words to the translation. To improve clarity in the genealogical passages, I have occasionally added explanations to assist the reader in determining who is who. I have ignored the usual scholarly practice of putting these interpolations in square brackets, to minimise visual 'noise' in the text. In cases where an explanation is too long or complex to be inserted in the text neatly and unobtrusively, my second approach is to provide additional information in footnotes. Again, I have tried to keep these to a minimum for the convenience of the reader.

This translation of the Viṣnu Purāna was undertaken with the inquisitive non-specialist reader in mind. No prior knowledge of Sanskrit or Hindu traditions is assumed, and I have tried to keep the number of Sanskrit 
terms to a minimum. There are some words for which no suitable English equivalent exists, especially philosophical terms and the names of various species of divine and semi-divine beings. These I have left untranslated.

Where I have translated selected Sanskrit terms, some specialists will not be pleased. For example, some will disapprove of my translation of brabman as the Absolute, or of the very common phrase namas te as 'I bow to you'. Specialists will have further legitimate quibbles with most if not all of the following: I have rendered the very common epithet mabätman simply as 'great', mahäbhāga as 'fortunate' or 'blessed' and prakrti as 'primal nature'. I have translated varna as 'community' or 'order', as the usual rendering of 'caste' is inadequate and deeply value-laden. The common epithet purusottama I have given as 'supreme spirit' or 'highest spirit', and bhagavant as 'Lord' or 'lord', the former for Viṣnu-Kṛ̣na as the supreme deity and the latter for other less-significant characters, such as 'lord of demons', 'lord of men', and so on. Dharma is a notoriously difficult term, as no single English word can account for its range of meanings. Accordingly, I have in some places left it untranslated, but in others, have rendered it as 'virtue', 'tradition' or 'religion', depending on the context. I am not very apologetic for these translations, as this text is aimed at the general reader and specialists can always consult the original at sites such as the Göttingen Register of Electronic Texts in Indian Languages (GRETIL) or the Digital Corpus of Sanskrit.

Frequent repetition of a word in close proximity is not a sin in Sanskrit composition, but it is irritating for the reader of English. For this reason, I have often substituted pronouns for proper names and vice versa. The Sanskrit text gives the name of the speaker of each passage in the form 'Parāśara said:' (parāśara uvāca), but I have dropped the word 'said' to reduce the tedium of repetition.

Most verses in the Viṣnu Purāna are complete, freestanding syntactical units, but occasionally two or three verses form a single sentence governed by a single verb. In such cases, I have moved words around to ensure the clarity of the translation. Bearing all this in mind, mine is not a wordfor-word rendering. Some forms in the root text will not be found in the English and some in the translation have no equivalent in the Sanskrit. Nevertheless, the overall sense of the root text has been preserved as accurately and parsimoniously as possible. 
I have already mentioned that the names Viṣnu and Kṛṣna are used interchangeably in our text as, according to this tradition, the two deities are one and the same entity. There are also several common epithets that are used more or less interchangeably for Viṣnu-Kṛ̣na. Kṛ̣na’’s father was named Vasudeva, and Vāsudeva with a long $\bar{a}$ is a patronymic. This very common epithet of Kṛ̣ṇa applies equally to Viṣnu himself. Nārāyaṇa is an epithet used somewhat more frequently for Viṣnu in the sense of the universal creator. Viṣnu-Kṛṇna is also referred to as Madhusūdana, meaning 'Subduer of Madhu'. This is a reference to an event that is only hinted at in the Viṣnu Purāna, in which the deity killed a demon of that name. This epithet, with its connotations of conquest, is used more frequently in contexts where a martial tone is called for, such as when Kṛ̣na is battling various demons. Three common epithets are applied equally to both aspects of the deity and without reference to any particular context. Hari is said to be derived from the verb $h r$ ('take away'), as the deity is the remover of evils. Acyuta means 'unfallen' and hence infallible or eternal, and Keśava, puzzlingly, means 'hairy', or perhaps 'slayer of Keśin', as is suggested in the Viṣnu Purāna.

Kṛṣna’s elder brother is called Balarāma, Baladeva and Balabhadra with equal frequency, but also Rāma and Samkarṣaṇa. For simplicity, I have standardised on the first name, Balarāma, even where the root text uses one of the other forms. ${ }^{\text {? }}$

Many of the deities of the Viṣnu Puranna are also referred to by their epithets. To relieve the burden of remembering multiple names and titles, I have often given the deity's name along with the epithet-for example, for Hiranyagarbha, I use 'Brahmā born of the golden egg'; for Śakra, 'mighty Indra'. You will also find Varuna, lord of waters, Yama, lord of death, and many others. The forms Sun, Moon and Earth with capital letters are used for the respective deities in their embodied forms, and sun, moon and earth (without capitals) for these entities in the usual sense of their mundane physical equivalents.

In English, the passive voice is usually avoided, yet Sanskrit authors delight in this construction. I have consistently recast passives, which are very common in the root text, in the active voice.

9 For a detailed study of the names of Balarāma, see Bigger (1998). 
The overriding concern of Sanskrit authors when composing verses is to preserve the integrity of the metre. If they are short of a syllable here or two syllables there, they have recourse to a range of inconsequential 'fillers'particles that carry little semantic weight. These include words such as $e v a, h i, v a i$, atha, tatah, ca and tu. Given that they contribute so little to the overall meaning of a verse, I have usually chosen to ignore them in the translation.

In addition to these particles, Sanskrit authors often use vocatives (direct forms of address or invocations of individuals by name-for example, 'O Viṣnu', 'O Kṛnnaa') to pad out a verse to satisfy the metre. As mentioned, Wilson omitted these vocatives and epithets entirely from his translation, but I feel that this significantly detracts from the overall flavour of the text. I have opted to retain them (without the anachronistic 'O'), but generally shifted them to the caesura between two hemistichs-that is, the break between two lines in the middle of each verse-which seems the most natural place for them in English. As Sanskrit authors used vocatives largely for euphonic effect, I have sought to do something similar.

In conclusion, I can do no better than quote directly from Wilson's elegant preface, which, while written nearly two hundred years ago, is again eerily appropriate for our own age of turbulence:

I trust, however ... that the translation of the Vishṇu Purána will be of service and of interest to the few, who in these times of utilitarian selfishness, conflicting opinion, party virulence, and political agitation, can find a resting place for their thoughts in the tranquil contemplation of those yet living pictures of the ancient world which are exhibited by the literature and mythology of the Hindus. (Wilson 1961: lxxii)

\section{References}

Adluri, S. (2019). Who is the Viṣnu of the Viṣnu Purāna? Purānic Studies: Proceedings of the Purana Section of the 17th World Sanskrit Conference, July 9-13, 2018 (pp. 47-78). Vancouver: University of British Columbia.

Austin, C. (2011). The mystery of the Syamantaka jewel: The intersection of genealogy and biography in the Harivamśa. Religions of South Asia, 5(1-2): 153-169. doi.org/10.1558/rosa.v5i1/2.153. 
Austin, C. (2014). The abduction of Śrī-Rukmin̄ī: Politics, genealogy and theology in Harivamía 87-90. Religious Studies and Theology, 33(1): 23-46. doi.org/10.1558/rsth.v33i1.23.

Austin, C.(2019).Pradyumna:Lover, Magician and Scion of the Avatāra. New York: Oxford University Press. doi.org/10.1093/oso/9780190054113.001.0001.

Bailey, G. (1995). Gaṇeśapurāna: Introduction, Translation, Notes and Index. Wiesbaden, Germany: Harrassowitz.

Bailey, G. (2018). Purāṇas. In K. Jacobsen, H. Basu, A. Malinar and V. Narayanan (eds), Brill's Encyclopedia of Hinduism Online. Leiden: Brill. doi.org/10.1163/ 2212-5019_beh_COM_2020070.

Bigger, A. (1998). Balarāma im Mahābhārata: Seine Darstellung im Rabmen des Textes und Seiner Entwicklung [Balarāma in Mahäbhärata: His Presentation in the Context of the Text and its Development]. Wiesbaden, Germany: Harrassowitz Verlag.

Brodbeck, S. (2019). Krishna's Lineage: The Harivamsha of Vyāsa's Mahäbhārata. New York: Oxford University Press.

Couture, A. (2014). Viṣnu. In K. Jacobsen, H. Basu, A. Malinar and V. Narayanan (eds), Brill's Encyclopedia of Hinduism Online. Leiden: Brill. doi.org/10.1163/ 2212-5019_beh_COM_1030070.

Doniger, W. (1981). The Rig Veda: An Anthology-One Hundred and Eight Hymns. New York: Penguin.

Dutt, M. (1896). A Prose English Translation of Vishnupuranam. Calcutta: Elysium Press.

Fleet, J. (1915). The ancient Indian water-clock. The Journal of the Royal Asiatic Society of Great Britain and Ireland, (April): 213-230. Available from: www. jstor.org/stable/25189309.

Goldman, R. (1984). The Rāmāyana of Välmìki: An Epic of Ancient India. Volume 1: Bālakānda. Princeton, NJ: Princeton University Press. doi.org/ 10.1515/9781400884551.

Goswami, C. (2005). Śrimad Bhāgavata Mahāpurāna. Gorakhpur, India: Gita Press.

Gupta, M. (1967). Śriśríviṣnupurāna: mūla śloka aur hiṃdi anuvādasabita. Gorakhpur, India: Gita Press.

Gupta, R. and Valpey, K. (2013). The Bhāgavata Purāna: Sacred Text and Living Tradition. New York: Columbia University Press. 
Hardy, F. (1983). Viraha-bhakti: The Early History of Krsna Devotion in South India. Delhi: Oxford University Press.

Hiltebeitel, A. (1999). Retbinking India's Oral and Classical Epics: Draupadī among Raputs, Muslims and Dalits. Chicago: University of Chicago Press. doi.org/10.7208/chicago/9780226340555.001.0001.

Holdrege, B. (2013). Sacred geography: Vraja-dhāman-Krishna embodied in geographic place and transcendent space. In R. Gupta and K. Valpey (eds), The Bhägavata Purāna: Sacred Text and Living Tradition (pp. 91-116). New York: Columbia University Press.

Jamison, S. and Brereton, J. (2014). The Rigveda: The Earliest Religious Poetry of India. New York: Oxford University Press.

Jansma, R. (1999). Evolution in the Vishnu Purana. Sunrise Magazine, April/May [n.p]. Available from: www.theosophy-nw.org/theosnw/world/asia/as-rudi.htm.

Matchett, F. (2001). Krșna, Lord or Avatāra? The Relationship between Krṣna and Vișnu in the Context of the Avatära Myth as Presented by the Harivamsia, the Viṣnupurāna and the Bhāgavatapurāna. Richmond, UK: Curzon.

Matchett, F. (2005). The purānas. In G. Flood (ed.), The Blackwell Companion to Hinduism (pp. 129-143). Oxford: Blackwell Publishers.

Monier-Williams, M. (1899). A Sanskrit-English Dictionary Etymologically and Philologically Arranged with Special Reference to Cognate Indo-European Languages. Oxford: Clarendon Press.

Pathak, M. (1997-99). The Critical Edition of the Vișnupurānam. 2 vols. Vadodara, India: Oriental Institute.

Preciado-Solis, B. (1984). The Kṛnna Cycle in the Purānas: Themes and Motifs in a Heroic Saga. New Delhi: Motilal Banarsidass.

Rao, V. (2007). Purānana. In S. Mittal and G. Thursby (eds), The Hindu World (pp. 97-115). New York: Routledge.

Rocher, L. (1986). The Purānas. Wiesbaden, Germany: Harrassowitz.

Sathaye, A. (2015). Crossing the Lines of Caste: Visvamitra and the Construction of Brabmin Power in Hindu Mythology. New York: Oxford University Press. doi.org/10.1093/acprof:oso/9780199341108.001.0001.

Satyamurti, C. (2015). Mababharata:A Modern Retelling. New York: W.W. Norton. 
Schreiner, P. (2002). Five topics, three functions, one god: On the interrelatedness of purānapañncalakșaṇa-material and trimūrti concept in the Viṣnupurāna. In M. Brockington (ed.), Stages and Transitions: Temporal and Historical Frameworks in Epic and Purānic Literature (pp. 261-286). Zagreb: Croatian Academy of Sciences and Arts.

Schreiner, P. (2013). Vișnupurāna: Althergebrachte Kunde über Viṣnu [Viṣnu Purāna: Traditional Lore about Vișnu]. Berlin: Verlag der Weltreligionen.

Sharma, R. (1985). The Viṣnumahāpurānam. Delhi: Nag Publishers.

Sukthankar, V. (1933-66). The Mahäbhārata. 19 vols. Poona, India: Bhandarkar Oriental Research Institute.

Taylor, M. (2007). The Fall of the Indigo Jackal: The Discourse of Division and Pürnabhadra's Pañcatantra. Albany, NY: State University of New York Press.

Taylor, M. (2016). Seven Days of Nectar: Contemporary Oral Performance of the Bhägavatapurāna. New York: Oxford University Press. doi.org/10.1093/ acprof:oso/9780190611910.001.0001.

Vaidya, L. (1969). The Harivamsia: Being the Khila or Supplement to the Mahābhārata. Poona, India: Bhandarkar Oriental Research Institute.

van Buitenen, J. (1973). The Mahäbhärata: The Book of the Beginning. Chicago: University of Chicago Press.

Wilson, H. (1961 [1840]). The Vishńu Purána: A System of Hindu Mythology and Tradition. 5 vols. Calcutta: Punthi Pustak. 
This text is taken from The Viṣnu Puranna: Ancient Annals of the God with Lotus Eyes, translated from the Sanskrit by McComas Taylor, published 2021 by ANU Press, The Australian National University, Canberra, Australia.

doi.org/10.22459/VP.2021.00 